\title{
CHEMICAL ADJUSTMENT OF EFFLUENT FROM CASSAVA PROCESSING PLANT PRIOR TO SAFE DISPOSAL
}

\author{
I. M. Jideofor \\ Dept. of Civil EngineEring, Michael OKPARA University of Agriculture, Umuahia, ABia STAte. NigERIA \\ Email address: ifymgj@yahoo.com
}

\begin{abstract}
The characteristics of cassava effluents are significantly affected by the various physical- chemical variables studied. The aim of this research is to attempt to chemically adjust the wastewater from cassava processing prior to safe disposal. Cassava waste water from a cassava processing plant in Nsukka was collected and chemically adjusted with $\mathrm{NaOH}$ at 6 levels of concentrations in the laboratory. The results showed that quick degradation of biochemical oxygen demand (BOD 5 ), total suspended solid(TSS) and Cyanide can be achieved by the addition of various degree of sodium hydroxide ( $\mathrm{NaOH}$ ). Higher degradation and odour removal was achieved faster with higher concentration of $\mathrm{NaOH}$ addition. However irrespective of the treatments applied degradation and stabilization of the effluent showed that it is a time dependent process. There were significant differences ( $p<$ 0.05) for coliform and cyanide at the determined daily intervals. Steep growth of coliform was more apparent in non treated effluent than oxidized effluent. $\mathrm{pH}$ of the effluent increased as the fermentation progresses by days irrespective of treatments.
\end{abstract}

Keywords. Cassava effluents, Sodium hydroxide, Degradation, Stabilization.

\section{INTRODUCTION}

Waste water effluent has become a major environmental problem especially in the developing countries. The lack of central sewage disposal system makes the treatment of this wastewater difficult. Several waste water effluents generated from industries and homes are discharged into the rivers, canals, surface ponds, shallow gutters and streams with serious consequences $[1,2]$. In Nigeria, among this category of environmental hazardous waste effluent is cassava waste water. Borgstrom [2] considered the scope of bioconversion of cassava and its by-product through fermentation as the oldest form of food biotechnology, in which wastewater can be generated copiously. This effluent is massively generated during cassava processing into various byproducts which includes fermentation and sifting into cassava pulp, grinding and dewatering for production of cassava derived products including flakes and starch [4-6].These processes requires large amount of water and it is estimated that the volume of combined wastewater from tapioca starch factory vary from 40 to $60 \mathrm{~m}^{3}$ per ton of starch in first-grade processing (traditional labour intensive) and from $20-40 \mathrm{~m}^{3}$ per ton of starch in the second-grade processing (highly mechanized) [7]. This waste water also contains varying concentration of heavy metals [8].

According to Okunade and Adekalu [2] cassava waste water with its high concentration of poisonous cyanide, contains also some chemically inert compounds which they categorized as low biochemical oxygen demand $\left(\mathrm{BOD}_{5}\right)$ compounds. Oti [9] also revealed that this cyanide forms complex compound with zinc or hydrogen to form an acidic complex called hydrogen cyanides acid. Cassava waste water degrades very quickly and spreads very offensive odour within the environment. According to Ekpechi [5] products of breakdown of both simple and complex cyanide from cassava poses various degree of consequences to the soil, soil microorganisms, water and plants. The cyanide effect on domestic animals has also been studied [10,11]. Obioha [11] also stated that the toxicity in cassava may be acute and/or chronic. Acute toxicity results from ingestion of a lethal dose and death may occur by the inhibition of cytochrome oxidase of the respiratory chain by cyanide. Atulegwu 
and Egwuonwu [12] concluded that with the high level of $\mathrm{pH}$ of cassava effluent, germination of seed seems to be inhibited. Therefore the consequence of not tackling cassava waste water effluent will be grave for Nigeria bearing in mind that Nigeria is among the world's largest producer of cassava and cassava by products. The quantity of cassava effluent generated from cassava processing in Nigeria is difficult to ascertain because of a lot of informal or undocumented processing for both subsistence and commercial purpose. Barana [13] however report that after anaerobic bio digestion, waste water from cassava can still be used for "fertirrigation", since the digestion processes does not substantially decrease the mineral content. There are two ways to tackle the problem of cassava effluent, either it is converted and utilized for industrial purposes in the production of paper, plywood, adhesives, sweeteners, monosodium glutamate, alcohol, amino acids, [7], as fertilizer [14], herbicide [15], insecticide [16], nematicide [17, 18], biosurfactant [19], substrate for micro organism growth [20] and recently as aromas [21] or chemically adjusted for safe disposal. The technology to apply the first option is not extensive in Nigeria, leaving many parts of the country at the mercy of the effluent. Ubalua [22] has highlighted several methods of treating cassava waste including waste water as follows: the utilization of aerobic and anaerobic lagoons which involves bringing the organic material into long contact with dense microorganism in the presence or absence of oxygen that creates a low amount of ammonia and hydrogen sulphide resulting in the odour removal. Other methods include the biofilm processes, phase separation [23], transfilter process [24] rustic biofilter bamboo horizontal flow etc. These methods are capital intensive and have been utilized by big industries in South America and Asia. However, Okunade and Adekalu [2], stated that no policy guidelines and specific method to safely dispose this hazardous waste in Nigeria. Therefore the aim of this research was to attempt to chemically adjust the waste water from cassava processing prior to safe disposal.

\section{MATERIAL AND METHOD}

\subsection{Sample Collection}

The waste water effluent used for the treatment was collected from a shallow sedimentation tank generated from the production of cassava flakes located at Nsukka $\left(6.86^{\circ} \mathrm{N}\right.$ and $\left.7.4^{\circ} \mathrm{E}\right)$, Enugu state South Eastern Nigeria. Nsukka (Fig. 1) is an urban area with a population of 309,633 as at 2006 Nigerian census [25] and covers an area of $45.38 \mathrm{~km}^{2}$. The variety of cassava was not ascertained because of different sources of procurement. However in the South Eastern Nigeria the major variety grown is classified based on the length of maturity. Therefore there are the early maturing cassava ( 6 months) and late maturing ( 1 year or more). The process involved in the processing includes cassava tuber peeling, washing, grating, dewatering or fermentation to produce fufu which generates a lot of waste water. The wastewater contains starch, some impurities and some fibres. The waste water generated from fermentation of the cassava for 4 days were sifted with a plastic sieve and collected in 50L plastic container and then transported to the civil engineering sanitary laboratory at the University of Nigeria Nsukka for further analysis for 20 days. Biochemical Oxygen Demand $\left(\mathrm{BOD}_{5}\right)$ test, coliform test, cyanide test, and total suspended solid test (TSS) were carried out immediately and at 5 days fermentation interval in the laboratory.

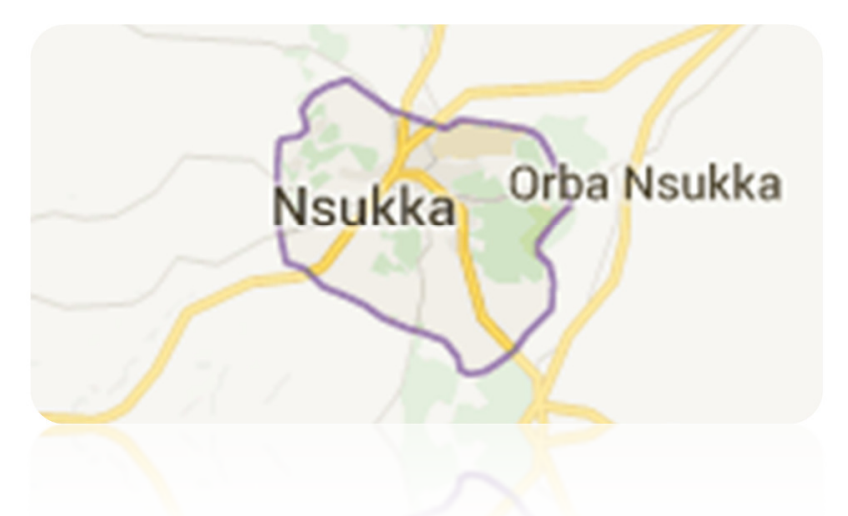

Fig. 1 map of Nsukka (maps.google.com)

\subsection{Experimental Procedure}

The study was laid out as a Completely Randomize Design with appropriate treatments and replication. Six clean plastic buckets were filled with two litres of cassava waste water each. The bucket was labelledY ${ }_{1}$, $Y_{2}, Y_{3}, Y_{4}, Y_{5}$ and $Y_{6}$, with $Y_{1}$ as the control experiment. $\mathrm{Y}_{2}-\mathrm{Y}_{6}$ sample was treated with Sodium Hydroxide $(\mathrm{NaOH})$. The chemical was added at $2 \mathrm{~g}, 4 \mathrm{~g}, 6 \mathrm{~g}, 8 \mathrm{~g}$, and $10 \mathrm{~g}$ into $\mathrm{Y}_{2}-\mathrm{Y}_{6}$ respectively and left for 20 days. Each treatment was replicated thrice and the average value recorded with standard deviation. The concentration of $\mathrm{pH}$, cyanide, BOD, TSS (suspended solid) was determined using the standard methods. The $\mathrm{pH}$ was determined by electrometric method using glass and reference electrode. The Coliform standard test was 
carried out using multiple tube fermentation technique, a series of fermentation tubes were inoculated with appropriate graduated quantities. In the test of cyanide Argentometric titration method was used with the rhodamine indicator. The use of the indicator turns the solution from yellow to brownish pink (salmon colour). Dilution method was used for determination of the biochemical oxygen demand as approved by American Public Health Association [26] and standard method $2540 \mathrm{D}$ was used for measuring the suspended solid.

\section{RESULTS AND DISCUSSION.}

\subsection{Effect of Chemical Treatment}

Cassava wastewater is characterized by offensive odour, black-ash colour and suspended solid. These offensive odours cause poor appetite for consumption of cassava food, impaired respiration, nausea; vomiting and mental perturbation and can distort the interest of water consumption when discharged to the river or stream without undergoing proper treatment [27]. However this observation was as a result of presence of some chemical constituents like sulphur, potassium, manganese etc. [13]. These constituents were chemically adjusted by applying different level of concentration of sodium hydroxide. The various results showed different level of the degradation of the compounds and $\mathrm{pH}$ value of the cassava wastewater effluent. The results of various responses to the chemical treatment of the cassava effluent are shown in Figures $2-6$. There were general decreases in TSS, BOD and cyanide value in figure 2-4 respectively as the concentration of $\mathrm{NaOH}$ increases. However the $\mathrm{pH}$ increased for all the treatments as expected because of the alkaline nature of $\mathrm{NAOH}$. The variation of the concentration total suspended solid test values (TSS) with days is shown as area plot in Figure 2. Higher rate of degradation of cyanide was observed in higher oxidants addition than lower oxidant addition as shown in Figure 4. The TSS degraded faster in $10 \mathrm{~g} \mathrm{NaOH}$ reaching its lowest value of $50 \mathrm{mg} / \mathrm{l}$ in 20 days. This value corresponds to $78.3 \%$ of the initial value compared to $54 \%$ degradation from non treated waste water at the same date. This shows that faster degradation and disposal of cassava waste water can be achieved with increased concentration with no harm to the environment. Most Cassava processing plants in Nigeria provides shallow tanks for effluents discharge which get easily filled and requires frequent disposal to create room for incoming effluents. However, with the consequences of this effluent to the environment, this becomes a problem to cassava processors because the effluents cannot be discharged from the tanks without degradation. Therefore, with chemical treatment resulting in faster degradation of constituent, effluents can be regularly disposed to free space for new once.

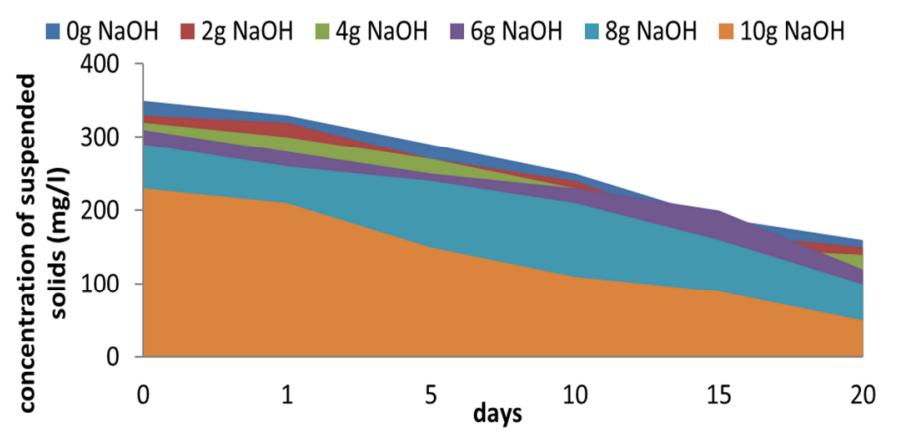

Fig. 2 Total suspended solid test values (TSS) (mg/l)

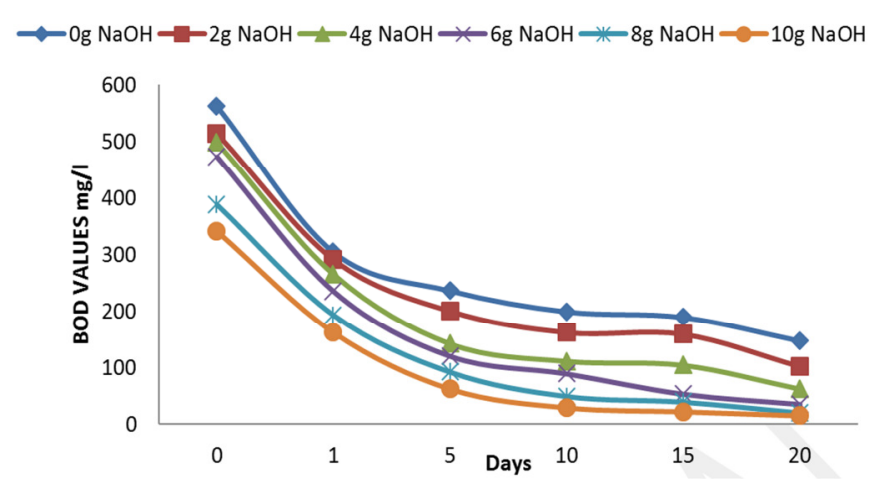

Fig. 3 Concentration of BOD $(\mathrm{mg} / \mathrm{l})$

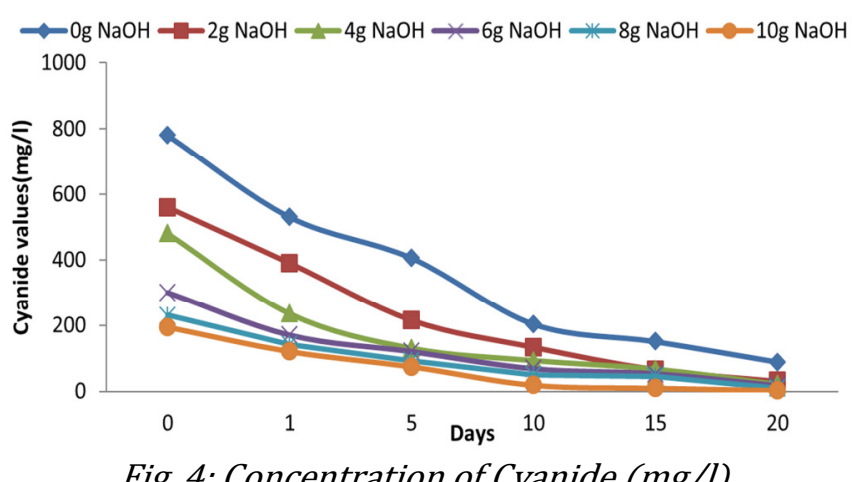

The same effect was recorded for BOD and Cyanide values for all the treatments. The addition of $\mathrm{NaOH}$ as an oxidizing agent quickens the degradation of $\mathrm{BOD}_{5}$ load. The rate of decay, increased as the concentration increased. In relative to 20 days of treatment, $99.54 \%$ of BOD $_{5}$ has degraded at $10 \mathrm{~g}$ oxidants addition compared to $90 \%$ at $8 \mathrm{~g}, 88.79 \%$ at $6 \mathrm{~g}, 79.11 \%$ at $4 \mathrm{~g}$, $69.06 \%$ at $2 \mathrm{~g}$ and $66.37 \%$ at $0 \mathrm{~g} .0 n$ the fifteenth day, the cassava effluent with 8 and $10 \mathrm{~g} \mathrm{NaOH}$ addition has become odourless with BOD less than $40 \mathrm{mg} / \mathrm{l}$. 
Figure 4 also showed that degradation of cyanide in cassava is also a function of time. However the addition of the oxidant also quickened the degradation of the cyanide. Increased $\mathrm{NaOH}$ resulted in faster degradation of the cyanide. For all the treatments the cyanide value approached zero value at 15 - 20 days of fermentation. However the values at 20 days for all treatments is above $2 \mathrm{mg} / \mathrm{l}$ which is still higher than maximum safe permissible level of cyanide for some countries like US, Canadian, Swiss and German regulations [28]. Therefore disposal into stream as it is done in some rural area will not be advisable due to the toxicity of cyanide to animals. Figure 5 showed that the $\mathrm{pH}$ value of the cassava effluent was affected by the treatments which are expected because of the alkalinity of $\mathrm{NaOH}$. This was more noticed at higher concentration of oxidant than the lower concentration. Maximum $\mathrm{pH}$ for the treatments at 20 days was 9.36, $9.22,8.74,8.64$ and 7.67 for the treatments from 2$10 \mathrm{~g} \mathrm{NaOH}$ respectively. The increased $\mathrm{pH}$ indicates that the concentration of the acid content of the waste water was neutralised by $\mathrm{NaOH}$. Cassava effluent is rich in nitrates and trace elements as it ferments [13], therefore may be useful as irrigation water for crops if fully degraded by chemical adjustment which can be performed in oxidation ponds. Figure 6 also show that high degree of coliform inhibition can be achieved with $6 \mathrm{gNaOH}$ or more. 2 - $4 \mathrm{~g}$ addition of $\mathrm{NaOH}$ did not significantly stop coliform growth. Although fig. 2-6 showed various levels of changes of the tested physiochemical constituents of the cassava effluent discharge at different level of $\mathrm{NaOH}$ addition for the 20 days period, however the analysis of variance in Table 1 - 5 showed that there were no significance difference for $\mathrm{BOD}_{5}$, TSS and $\mathrm{pH}$ while coliform and cyanide showed significant difference at $\mathrm{p}<0.05$.

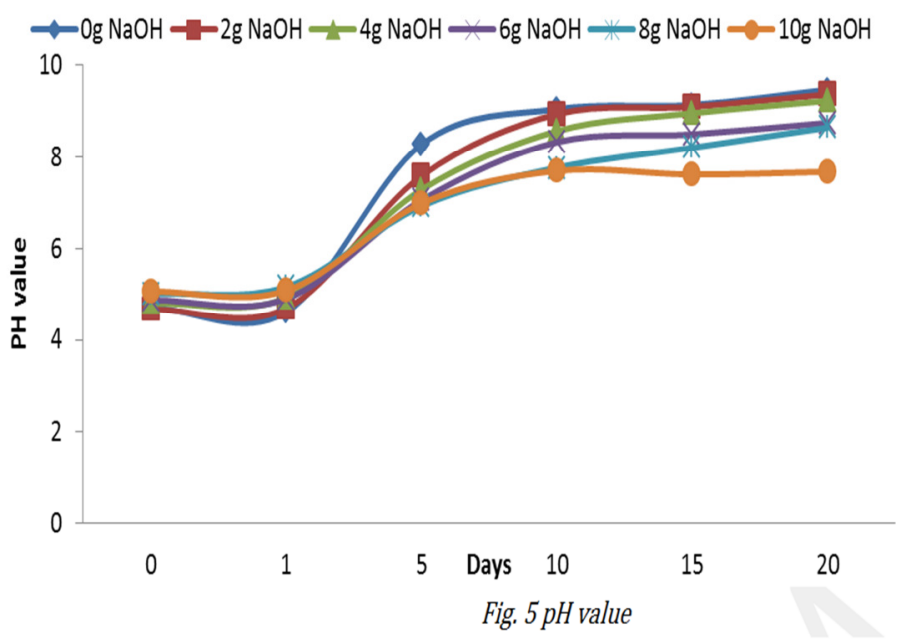

Fig. 5 pH value

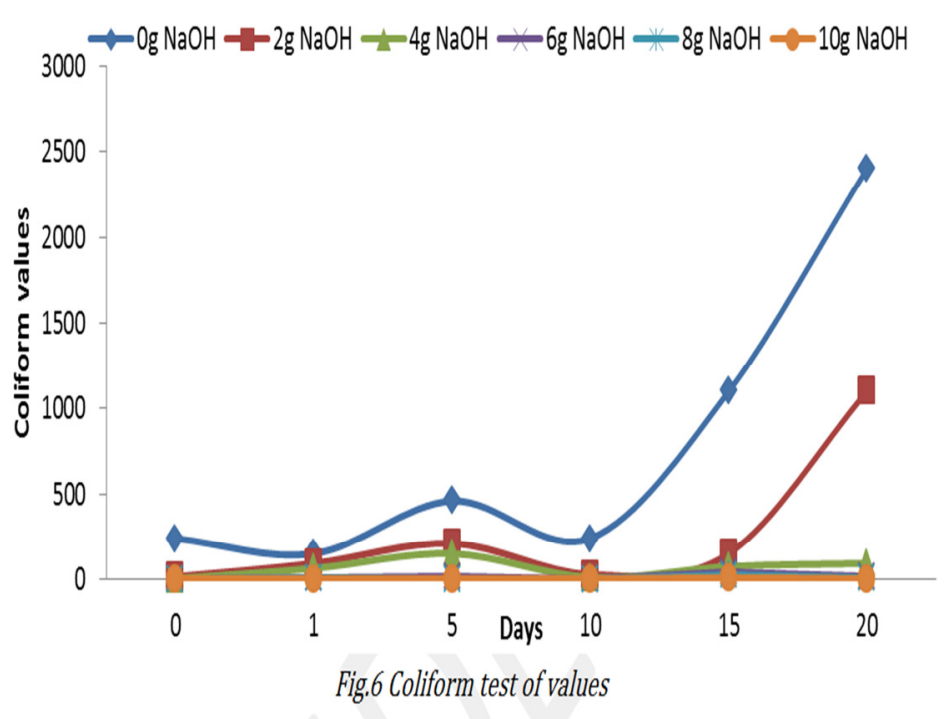

Fig. 6 Coliform test of values

Table 1: ANOVA test for TSS

\begin{tabular}{|c|c|c|c|c|c|c|}
\hline \multicolumn{7}{|l|}{ Anova: Single Factor } \\
\hline \multicolumn{7}{|l|}{ SUMMARY } \\
\hline Groups & Number of treatments & Sum & Average & Variance & & \\
\hline Og NAOH & 6 & 1570 & 261.6667 & 5776.667 & & \\
\hline $2.0 \mathrm{~g} \mathrm{NAOH}$ & 6 & 1480 & 246.6667 & 5626.667 & & \\
\hline $4.0 \mathrm{~g} \mathrm{NAOH}$ & 6 & 1410 & 235 & 5790 & & \\
\hline $6.0 \mathrm{~g} \mathrm{NAOH}$ & 6 & 1390 & 231.6667 & 4456.667 & & \\
\hline 8.0g NAOH & 6 & 1260 & 210 & 4880 & & \\
\hline $10.0 \mathrm{~g} \mathrm{NAOH}$ & 6 & 840 & 140 & 4920 & & \\
\hline ANOVA & & & & & & \\
\hline Source of Variation & SS & $d f$ & $M S$ & $F$ & $P$-value & F crit \\
\hline Between Groups & 55825 & 5 & 11165 & 2.130048 & 0.089038 & 2.533555 \\
\hline Within Groups & 157250 & 30 & 5241.667 & & & \\
\hline Total & 213075 & 35 & & & & \\
\hline
\end{tabular}


Table 2: ANOVA test for $\mathrm{BOD}_{5}$

Anova: Single Factor

\section{SUMMARY}

\begin{tabular}{|c|c|c|c|c|c|c|}
\hline Groups & Number of treatments & Sum & Average & Variance & & \\
\hline $0 \mathrm{~g} \mathrm{NAOH}$ & 6 & 1637 & 272.8333 & 22851.77 & & \\
\hline $2.0 \mathrm{~g} \mathrm{NAOH}$ & 6 & 1428 & 238 & 22188.4 & & \\
\hline $4.0 \mathrm{~g} \mathrm{NAOH}$ & 6 & 1182 & 197 & 26504 & & \\
\hline $6.0 \mathrm{~g} \mathrm{NAOH}$ & 6 & 1005 & 167.5 & 27394.3 & & \\
\hline 8.0g NAOH & 6 & 781 & 130.1667 & 19783.77 & & \\
\hline $10.0 \mathrm{~g} \mathrm{NAOH}$ & 6 & 631 & 105.1667 & 16311.77 & & \\
\hline \multicolumn{7}{|l|}{ ANOVA } \\
\hline Source of Variation & $S S$ & $d f$ & $M S$ & $F$ & $P$-value & F crit \\
\hline Between Groups & 122123.6 & 5 & 24424.71 & 1.085269 & 0.388569 & 2.533555 \\
\hline Within Groups & 675170 & 30 & 22505.67 & & & \\
\hline Total & 797293.6 & 35 & & & & \\
\hline
\end{tabular}

Table 3. ANOVA test for cyanide

\begin{tabular}{|c|c|c|c|c|c|c|}
\hline Anova: Single Factor & & & & & & \\
\hline SUMMARY & & & & & & \\
\hline Groups & Number of treatments & Sum & Average & Variance & & \\
\hline 0g NAOH & 6 & 2156 & 359.3333 & 70011.07 & & \\
\hline $2.0 \mathrm{~g} \mathrm{NAOH}$ & 6 & 1393 & 232.1667 & 42266.17 & & \\
\hline $4.0 \mathrm{~g} \mathrm{NAOH}$ & 6 & 1026 & 171 & 28131.6 & & \\
\hline $6.0 \mathrm{~g} \mathrm{NAOH}$ & 6 & 728 & 121.3333 & 10538.27 & & \\
\hline $8.0 \mathrm{~g} \mathrm{NAOH}$ & 6 & 566 & 94.33333 & 6441.067 & & \\
\hline $10.0 \mathrm{~g} \mathrm{NAOH}$ & 6 & 417 & 69.5 & 5787.9 & & \\
\hline ANOVA & & & & & & \\
\hline Source of Variation & $S S$ & $d f$ & $M S$ & $F$ & $P$-value & $F_{\text {crit }}$ \\
\hline Between Groups & 346676.2 & 5 & 69335.24 & 2.549464 & 0.048882 & 2.533555 \\
\hline Within Groups & 815880.3 & 30 & 27196.01 & & & \\
\hline Total & 1162557 & 35 & & & & \\
\hline
\end{tabular}

Table 4. ANOVA test for colliform

\begin{tabular}{|c|c|c|c|c|c|c|}
\hline \multicolumn{7}{|l|}{ Anova: Single Factor } \\
\hline \multicolumn{7}{|l|}{ SUMMARY } \\
\hline Groups & Number of treatments & Sum & Average & Variance & & \\
\hline $0 \mathrm{~g} \mathrm{NAOH}$ & 6 & 4590 & 765 & 761590 & & \\
\hline $2.0 \mathrm{~g} \mathrm{NAOH}$ & 6 & 1596 & 266 & 172344.4 & & \\
\hline $4.0 \mathrm{~g} \mathrm{NAOH}$ & 6 & 397 & 66.16667 & 2947.767 & & \\
\hline $6.0 \mathrm{~g} \mathrm{NAOH}$ & 6 & 91 & 15.16667 & 212.9667 & & \\
\hline 8.0g NAOH & 6 & 51 & 8.5 & 59.9 & & \\
\hline $10.0 \mathrm{~g} \mathrm{NAOH}$ & 6 & 25 & 4.166667 & 5.766667 & & \\
\hline \multicolumn{7}{|l|}{ ANOVA } \\
\hline Source of Variation & $S S$ & $d f$ & $M S$ & $F$ & $P$-value & Fcrit \\
\hline Between Groups & 2698447 & 5 & 539689.4 & 3.455262 & 0.013879 & 2.533555 \\
\hline Within Groups & 4685804 & 30 & 156193.5 & & & \\
\hline Total & 7384251 & 35 & & & & \\
\hline
\end{tabular}


Table 5: ANOVA test for $p H$

\begin{tabular}{|c|c|c|c|c|c|c|}
\hline \multicolumn{7}{|l|}{ Anova: Single Factor } \\
\hline \multicolumn{7}{|l|}{ SUMMARY } \\
\hline Groups & Number & Sum & Average & Variance & & \\
\hline $0 \mathrm{~g} \mathrm{NaOH}$ & 6 & 45.22 & 7.536667 & 5.118227 & & \\
\hline $2.0 \mathrm{~g} \mathrm{NaOH}$ & 6 & 44.32 & 7.386667 & 4.773387 & & \\
\hline $4.0 \mathrm{~g} \mathrm{NaOH}$ & 6 & 43.73 & 7.288333 & 3.982097 & & \\
\hline $6.0 \mathrm{~g} \mathrm{NaOH}$ & 6 & 42.37 & 7.061667 & 3.183337 & & \\
\hline $8.0 \mathrm{~g} \mathrm{NaOH}$ & 6 & 41.69 & 6.948333 & 2.408657 & & \\
\hline $10.0 \mathrm{~g} \mathrm{NaOH}$ & 6 & 40.09 & 6.681667 & 1.627897 & & \\
\hline \multicolumn{7}{|l|}{ ANOVA } \\
\hline Source of Variation & $S S$ & $d f$ & $M S$ & $F$ & $P$-value & $F$ crit \\
\hline Between Groups & 2.954789 & 5 & 0.590958 & 0.168096 & 0.97239 & 2.533555 \\
\hline Within Groups & 105.468 & 30 & 3.5156 & & & \\
\hline Total & 108.4228 & 35 & & & & \\
\hline
\end{tabular}

\section{CONCLUSION}

The characteristics of cassava effluents are significantly affected by the various physiochemical variables studied. Although the degradation of BOD, TSS and Cyanide occurs as the effluent naturally ferments but they occur at a very slow pace. Addition of various degree of $\mathrm{NaOH}$ affected the rate of their degradation. Higher degradation and odour removal was achieved faster with higher concentration of $\mathrm{NaOH}$ addition. However irrespective of the treatments applied degradation and stabilization of the effluent show that it is a time dependent process. There was significant difference $(\mathrm{P}<0.05)$ for the various variables at the determined daily intervals. Rapid increase of coliform was more apparent in non treated effluent than oxidized effluent. The $\mathrm{pH}$ of the effluent increased as the fermentation progresses by days irrespective of treatments. Most farmers cultivate cassava with nitrogenous fertilizers, this high the amount of nitrate content in cassava tubers and when dispose the waste effluent on land and stream leads to high nitrates (eutrophication). However sodium hydroxide results in increase enhancement of the nitrate which suggest that if the effluent is completely degraded and acceptable $\mathrm{Na}^{+}$adsorption ratio achieved, it can be useful in irrigation of plants.

\section{ACKNOWLEDGEMENT}

Special thanks to the staff of Civil Engineering sanitary laboratory, University of Nigeria Nsukka and to Dr. M. $\mathrm{U}$ Ndukwu for his assistance to make the paper a success.

\section{REFERENCES}

[1] Akpan, I, and Ikenebomeh, MJ, "Glutamic Acid Fermentation" Nig. J.Microbiol. 10, 60-65. 1995.
[2] Alazard D., "operation 2.Traitment des dechetssolideseet liquids. In: Vaporization des produitset sous-produits et sous-produits de la petite et mayenneindustrie de transformation du manioc en". Ameriquelatine. Rapport final 19921995.CotratCEETS 3- CT92 -0110.PP100-136.

[3] APHA, "Standard methods for the examination of water and wastewater", 20 th Ed. Washington D.C, American Pulblic Health Association. 1985.

[4] AtulegwuP.U, and Egwuonwu N, "quality Assessment of the mill effluent polluted Eutric- tropoflurent soil".Research Journal of Environmental Science. 5:342-353, 2011.

[5] Balagopalan, C., and Rajalakshmy.L."Cyanogen accumulation in environment during processing of cassava (ManihotesculentaCrantz) for starch and sago". Water, Air and Soil Pollution 102 (3-4), 407413, 1998.

[6] Barana AC, "Avaliacao de tratemento de manipueriaembiodestoresfaseacidogenica e metangenica". Botucatu: UNESP/FCA, P.95(TESEDoutorado), 2000.

[7] Bengtsson, B.E, and Trient, T.. "Tapioca-Starch Waste Water Toxicity Characterized by microtox and duck week tests" Ambio. 23: 473-477.1994.

[8] Borgstrom, G. "Principles of Food Science" Vol. 2. Food Microbiology and Biochemistry. New York, Macmillan. 1968.

[9] Campbell-Platt, G. . "Fermented Foods - a World Perspective” Food Res. Int. 27: 253. 1994.

[10] Ekpechi, O.L. "Cassava Cyanogenesis and Iodine Deficiency Disorders"-Cassava Safety.Acta Horticulturae 375, 289-293, 1994.

[11] Farinate, 1993 in Ubalua A.O. "cassava wastes: treatment options and value addition alternatives". African Journal of Biotechnology. Vol. 6 (18), pp 2065-2073, 2007

[12] Fioretto RA "efeito da manicpuieraaplicadaem solo cultivadocom.mandioca (manihotesculentacrantz)", 
BotucatuUNESP/FCA p.112 (dissertacao-mestrado). 1985.

[13] Herny G, Howeler R. "Cassava in china in an era of change". A CBN case study with farmers and processors working document, No. 155.CIAT, Cali, Columbia p. 18, 1996.

[14] Igbozuruike, C.W.I., A.O. Opara- Nadi and I.K. Okorie, "Concentrations of heavy metals in soil and cassava plant on sewage sludge dump". Proceedings of the 16th International Plant Nutrition Colloquium, July 8, International Plant Nutrition Colloquium, pp: 152160. 2009.

[15] Iyayi, EA. Tewe 0.0., and Oki, RT. "Processing Cassava Leaves for Broiler Production in South West Nigeria". Nationally Coordinated Research Project (NCRP53), University of Ibadan, 1997.

[16] J. E. Ehiagbonare, S. A. Enabulele, B.B. Babatunde and R. Adjarhore, "Effect of cassava effluent on Okada denizens".Scientific Research and Essay Vol.4 (4), pp. 310-313, 2009.

[17] Metcalf \& Eddy, "Wastewater Engineering Treatment and Reuse" $4^{\text {th }}$ edition, McGraw Hill Publication, New York, 72, 1650-1658, 2004.

[18] Obioha, F.C, and Anikwe, P.C.N. "Utilization of Ensiled and Sun Dried Cassava Peels by Growing Swine" Nutri Rep. Int. 26(6), 961-972, 1986.

[19] Okoye U.O .Knowledge and awareness of the child right act among residence of university town in Nigeria. Educational Research vol. 2 , no. 10 pp 1595 - 1601. 2011

[20] Okunade, D.A. and Adekalu, K.O."Physiochemical Analysis of Contaminated Water Resources Due to Cassava Wastewater Effluent Disposal" European International Journal of Science and Technology Vol. 2 No. 6 pp 75-85, 2013.

[21] Oliveira, M.A., Reis, E.M., and Nozaki, J. "Biokenetic parameters investigation for biological treatment of cassava mill effluents". Water, Air and Soil Pollution 126(3-4), 307-319, 2001.

[22] Oti, E.E., "Acute toxicity of cassava mill effluent to the African catfish fingerlings". J. Aquat. Sci., 17: 3134. 2002.
[23] Ponte JJ da, "uso da manipueiracomoinsumo Agricola: defensive e fertilizante. In: Cerda, M.P. manejo, usoetratemente de subprodutos da industrializacao da mandioca". Sao Paulo: Fundacaocarg ill. Pp 80-95, 2001.

[24] Ponte JJ da, Franco A, Santos JHR."Eficiencia da manipueira no controle de duaspragas da citricultura. In:congress Brasileira de mandioca p 59, 1992.

[25] Ponte JJ da, Franco A. "Manipueira, Um nematicidanaoconvencional de comprovadapotencialidade", NematologiaBrasileira, 7:21-25, 1983.

[26] Raddatz, W. "The possibility of anaerobic treatment of wastes and wastewater from small and medium agro-industries": Sisal and Cassava Starch Production. CVC, Cali, Colombia, 1986.

[27] Ribas, M.M. Barana, A.C. "Start-up adjustment of a plug-flow digester for cassava wastewater (manipueira) treatment". Scientia Agricola, v.60, n.2, p.223-229, Abr/Jun, 2003.

[28] Santos CFC, Pastore GM, Damasceno S, Cereda MP, "producao de biosurfactantesporlinhagens de Bacillus

SubtilisUtilizandomanipueiracornosubstrato", revistaciencia e Tecnologia de Alimentre 33:157161,2000

[29] SenaES, Ponte JJde, "a Manipueira no controle da meloidoginose da cenoura. Nematologia Brasileira, 6:95-98, 1982.

[30] Steinkraus, KH. "Handbook of Indigenous Fermented Foods" New York, Marcel Dekker, 1995

[31] Wosiaacki G, Fioretto AMC, Cereda PM, "utilizacoa da manipueiraparaproducao de biomasssokaginosa. In: ceredaM.P. Resdua da indusrtrializacao da mandioca. Sao Paulo: pauliceia pp.151-161, 1994.

[32] Ubalua A.O. "Cassava wastes: treatment options and value addition alternatives". African Journal of Biotechnology. Vol. 6 (18), pp 2065-2073, 2007. 